\title{
MINORITY LANGUAGE POLICY REGARDING PERSONAL NAMES - AN OVERVIEW
}

\author{
Justyna Walkowiak \\ Adam Mickiewicz University
}

\begin{abstract}
Language Policy (LP) with language planning as its implementation is now a well-established field; yet, as evidenced by the scarcity of scholarly literature, seldom concerned with personal names. The paper looks at personal names (given names and surnames) and discusses the ways in which they can be perceived as objects of minority LP. Policies regarding personal names are analysed within the framework of the traditional division of language planning into status, corpus and acquisition planning. These policies are then further examined according to other dimensions: what the object of a LP is, who its agent is, what motivates a LP, what effects it exerts, and how a LP is carried out. Finally, the paper looks at EU minority legislation with reference to personal names, especially at the country-specific opinions which reflect the FCNM monitoring process, highlighting areas of controversy. In conclusion, it is shown how vital personal names are to personal and group identity and, consequently, how control over them helps the nation-state control a minority, although - it is argued - not every regulation constitutes a minority LP.
\end{abstract}

Keywords: language policy, minorities, personal names, surnames, given names

\section{Introduction}

The aim of this paper is to look at personal names (henceforth PNs) ${ }^{1}$ as objects of language policy (henceforth LP), to consider how they could be analysed within the traditional LP categories, to suggest which of their aspects should be taken into account in their analysis, finally to see contemporary European minority policies regarding PNs in the light of the current EU regulations.

1 In what follows, under the term 'personal names' are to be understood only surnames (family names), including patronymics, and given (first) names, to the exclusion of, for example, nicknames or noms de plume. 
According to James Crawford (2009), LP is what government does officially - through legislation, court decisions, executive action, or other means - to (a) determine how languages are used in public contexts, (b) cultivate language skills needed to meet national priorities, or (c) establish the rights of individuals or groups to learn, use, and maintain languages. [emphasis added]

Shohamy (2006), on the other hand, stresses the existence of 'de facto' LPs which may be created even in the absence of any officially codified policies and makes a distinction between overt and covert mechanisms (for this distinction, see also Schiffman 1998, and Huebner, Davis, and Lo Bianco 1999). As Huebner points out, both overt and covert language policies apply within sociocultural, historical contexts which are not part of the explicit policy, but which define the form and content of policy. Cultural generalizations about attitudes and orientations toward language are a part of a wider set of practices, values, and beliefs, which underlie language policy and language practice decisions. (Huebner et al. 1999: 5)

For instance, among Slavic peoples the introduction of Christianity led, sooner or later and to varying degrees, to the abandonment of traditional two-part names, to the advantage of the borrowed Christian ones, the process accelerated considerably by the Council of Trent (1545-1563). While larger communities might have been relatively resistant to this change, the small ones were not, especially where the new law was enforced rigidly. As a result of the disappearance of a plethora of traditional Slavic names, which were seen as pagan and thus unsuitable, in the 18thcentury Croatia the entire system of given names was reduced to just 40 masculine names and as few as 20 feminine ones. In the same period $50 \%$ of the inhabitants of the area in and near Dubrovnik (and 60\% of the women and girls) carried just 5 given names (Rzetelska-Feleszko 2003-2004: 5-6) ${ }^{2}$

Needless to say, overt LPs also feature heavily in the history of official regulation of personal names, as further examples show.

2 An interesting example of how church practice influenced onomasticon, thus becoming a de facto policy, comes from the medieval Orthodox church in Russia. Between the 11th and the 13th centuries the number of Christian names in calendars was about one third of the present number for men and about one quarter of the present number for women. This was due to the practice of the Orthodox monks who, rewriting the church books, kept adding names of new martyrs, and these additions gradually found their way into the lists of names used for baptizing (Superanskaja 1995). 


\section{How can the theoretical framework of LP be adapted to personal names}

A nation-state's LP is reflected in language planning. ${ }^{3}$ The commonly accepted division of the latter into corpus planning, status planning (Kloss 1969: 81-83) and acquisition planning can only partially be adapted to the analysis of PNs as objects of LP. For instance, we could think of an official list of acceptable (or, conversely, forbidden) given names, and such lists exist or existed in many European countries, as a manifestation of corpus planning.

Looking at the three traditionally recognized types of corpus planning (graphization, standardization, modernization) we can also find analogies. Graphization in the sense of the "development, selection and modification of scripts and orthographic conventions for a language" (Liddicoat 2005: 995) is reflected in the sphere of PNs when names are required to contain only elements of a particular script. A case in point might be the requirement that Polish given names should not contain letters "x" or "v", which are alien to the Polish alphabet and used only for non-assimilated loanwords. Thus Ksenia, not Xenia, and Wiolet(t)a, not Violet(t)a, are accepted (Zalecenia 1996). This regulation is not directed against any particular minority, as no Polish minorities use languages that contain this letter. However, a seemingly similar prohibition in Turkey is directed against minorities (the Kurdish minority, specifically): letters " $x$ ", " $w$ " and " $q$ " are forbidden in given and family names in Turkey. Unlike Turkish, Kurdish uses these letters. Similarly Lithuanian registry offices do not use diacritics, thus distorting the orthography of Polish and German minority names.

As regards standardization, registry offices in Poland are instructed to choose Maria over its regional variant Maryja, though sometimes two variants of the same name are accepted (e.g. Apolinary alongside Apolinariusz). Such practices may eliminate regional (minority) variants, which in post-revolutionary France befell Breton variants of Christian names outside Brittany. Standardization can also occur within the set of minority PNs - thus in Poland only recently have Kashubian given names been standardized (Breza 2008: 98). In a microscale standardization occurs, for

\footnotetext{
For some scholars, language policy and language planning are interchangeable; for others, complementary (LPP) or completely different. Taking a stance on that issue does not seem necessary for the purpose of the present paper.
} 
instance, when, in case of doubt, the head of a local registry office in Poland chooses one variant of a first name or surname of those already used in documents (Ustawa 2005).

Finally, there is modernization, "when a language needs to expand its resources to meet functions" (Modernization, n.d.) For example, a decade ago in Poland there used to be an official list of 655 male and 521 female given names for parents to choose from (Malec 2001: 69), but the pressure from parents led to the acceptance and consequently the addition of new names, such as Jaśmina (a new coinage), Sonia (controversial since regarded merely a diminutive of Zofia, though at present borne by thousands of women in Poland) or Jarowit (a recently revived Slavic name of a pagan god).

When - as in the Polish regulations - there is an explicitly expressed requirement that names given to children should be in the form assimilated to the Polish language: Jan, not John or Johann; Katarzyna, not Catherine; Klara, not the Latin Clara or the Italian Chiara; Małgorzata and not Margareta; Marcin, not Martin; Piotr, not Peter (Ustawa 2005), this preference given to the national language variant over that of a minority or foreign language could be perceived as status planning.

\section{Towards a typology of language policies regarding personal names}

LP in the sphere of PNs may include only given names (as in Calvin's Geneva of the 16th century, see Naphy 2003: 144-149; McKim 2004: 31, Eire 1986: 316), only surnames (as in the Czech Republic until the law of 2004 (Ponikelska 2004) - most countries at some point in their history made surnames obligatory, e.g. the Danish Name Law of 1828 required all families to choose a permanent family name - or both. Obviously, a LP regarding PNs may be a standalone or part of a more comprehensive LP or other policies.

The source of a given LP in the domain of PNs could be the authorities (the government, the parliament, the monarch, etc.), or other polities: religious organizations (baptismal and monastic names in the Catholic and the Orthodox churches; new names of converts to Hinduism) or secular ones (the so-called 'monastic names' - in fact pseudonyms consisting of a given name and a surname - among the Freemasons). Also institutions, e.g. educational, have influence 
on PNs. For instance in Israeli kindergartens the language of instruction is Hebrew and, consequently, Palestinian children, similarly to immigrants' children, are addressed by Hebrew names (Spolsky and Shohamy 1999: 123). Another example might be the story of a woman born 1918 in Bochum, Germany, to a couple of Polish economic migrants, who, following Poland's regaining independence, returned to the Polish Pomerania. She recollects:

I went to primary school in 1927. [...] My name was changed by my form teacher. When I introduced myself as Greta, he said that from that moment I was to be called Małgorzata and that's how I was entered in the school register. He did not even talk about it to my parents. (Błaszczyk 2006: 32, translation from Polish by the present author)

Finally, individual(s) on the grassroots level could also exert their influence. While the above-mentioned options (authorities, religious organizations, institutions) seem rather obvious LP sources, the last one merits a mention as rather infrequent. In 1910 Sabino Arana, the founder of Basque nationalism, compiled and subsequently published a list of the Basque (i.e. non-Romance) versions of the names of Catholic saints. As Joaquin Gorrochategui writes, "in a spirit more suited perhaps to Esperanto than to a language with its own history, he laid down that women's names should end in -(n)e, while masculine names would end in -a, -i or in a consonant. [...] The antihistorical conception of all this can be seen clearly when he proposes Eneka as a man's name and Eneke as a woman's name, neither of which had existed previously" (1995: 752). The result was the creation of names almost ex nihilo (by translation from Spanish or by derivation guided by rules which had little to do with the actually attested phonetic processes). Interestingly, many of these arbitrarily coined names were eventually accepted and adopted by the Basques.

The motivation behind a LP affecting a minority could be nationalistic - e.g. the Polonization of German names and surnames in Silesia, Masuria and Warmia after World War II, which included almost 100,000 people (Linek 1997, Madajczyk 1999); political - in the Kingdom of Jordan, according to an October 2002 law, names such as Usama bin Laden, Binyamin Netanyahu, Yitzak Rabin or Golda Meir were not allowed for newborns in civil registry records (George 2005: 56); cultural - when the dominant culture is perceived as superior to the minority cultures; linguistic (language purism); religious / atheist - in the communist Albania 
under Enver Hoxha parents were not allowed to give their children religious names ${ }^{4}$. In 1982 a dictionary with 3,000 officially accepted secular names was published (Couretas 2008, Zanga 1986). Other motivating factor could be bureaucratic efficiency (many European countries, from the 18th century onwards, made Jews assume family names, and those were typically German-based), or a combination of the above (thus the requirement that names given to newborns in Poland and many other European countries should only be written with the Latin alphabet combines linguistic motivation with bureaucratic convenience). Often there is an overlap of several of the above motivating factors.

The effect of a LP could be assimilation, when a particular group affected by a LP becomes as a result more similar to another - typically a minority group being made more similar to a majority group. Examples abound. Thus, for instance, from the 15th century onwards the Guanches on the Canary Islands were forcibly baptized and on this occasion given new Spanish names of Christian saints, as well as, later, surnames of their Spanish godfathers (Andrews, Quintero, and O'Brien 2007: 29). In Greece under the dictatorship of Metaxas, Slavic surnames were compulsorily changed to Greek ones. In Italy under Mussolini, Croatian surnames were Italianized (Dizdar 2005). In Bulgaria under Todor Zhivkov given and family names of Pomaks and Turks were forcibly Bulgarized (Eberhardt 2005, Angelov and Marshall 2006, Majuk, n.d.).

The opposite phenomenon is dissimilation. Thus under Nazi occupation in Poznań and Łódź since 1940 it was forbidden to give German children "shocking (objectionable) names, and similarly foreign or Jewish names, are not to be registered" (SarnowskaGiefing 2003: 102, translation from German by the present author). The Poznań Civil Registry had at its disposal a list of 205 male and 193 female names that were considered to be German enough. Conversely, all Polish children were to be given only what Nazist perceived as 'Polish' names from an approved list, one of these being the obligatory Kazimierz/Kazimiera (SarnowskaGiefing 2003, Umińska-Tytoń 1988).

Yet another effect is the situation where alongside the official majority name for official use, there exists the private minority

\footnotetext{
This was a de facto anti-minority LP, since in effect Greek PNs were affected (which was accompanied by place-name changes in the ethnic Greek south, wherever villages had been named after saints).
} 
name for private use. This is still often the case with the Roma in Europe. Also Islamised Christians in the Balkans from the 18th century onwards used the Muslim name officially and a Christian one in private contexts (Kulavkova 2007: 88). A different attempt at resolving the majority/minority conflict is the so-called 'duckrabbit names' (Karagiannis 2005: 158), which seem to belong to both the majority and the minority culture alike.

LP regarding given names could be manifested as (semi-)official lists of acceptable names for newborns. There may be forbidden names, e.g. Kurdish names in Turkey (Skutnabb-Kangas and Bucak 1995). There may be a list of obligatory names: in Wartheland in Poland under Nazi occupation the approved list of names perceived as Slavic comprised 354 male and 213 female names. There may be a category of obligatory names: Dutch parents of Moroccan or Turkish origin are only allowed to choose a name from a list drawn up by Moroccan and Turkish authorities respectively. Originally meant as a token of tolerance on the part of the host country, the policy seems to have backfired, jeopardizing the assimilation of immigrants who are bound to be stigmatised against their wish (Szczerkowski 2007). Finally, there may be favoured names: in the years 1926-39, by decree of Poland's president Ignacy Mościcki, the seventh son of each purely Polish family with a clean criminal record could be the president's godson baptised Ignacy. This entailed such benefits as free healthcare, public transport and education on all levels, both in Poland and abroad. There were about 500 beneficiaries of this regulation (Matusz 2008).

With surnames, there seem to be fewer options, the first one historically being probably the very imposition of obligatory surnames - e.g. Jews since the end of the 18th century were required to assume surnames in many European countries. After surnames stabilized, there were numerous attempts to enforce (Bulgaria in the 1980s) or encourage (Estonia in the 1930s) their change from minority to majority form to manifest national unity.

\section{The EU regulations}

While the Charter of Paris for a New Europe (Nov. 21, 1990) indirectly referred to the right of minority members to minority PNs ("the ethnic, cultural, linguistic and religious identity of national minorities will be protected"), an explicit reference to per- 
sonal names was made in Article 11 of CEI Instrument for the Protection of Minority Rights (Nov. 19, 1994): "Any person belonging to a national minority shall have the right to use his or her surname and first names in his or her language and the right to official acceptance and registration of such surname and names".

The issue of PNs appears as well in bilateral treaties between various European states. However, the document that explicitly refers to PNs of minorities is the Framework Convention for the Protection of National Minorities (Strasbourg, Feb. 1995). As stated in article 11, point 1 of the FCNM, The Parties undertake to recognise that every person belonging to a national minority has the right to use his or her surname (patronym) and first names in the minority language and the right to official recognition of them, according to modalities provided for in their legal system.

Coupled with the explanatory report, which states that the authorities need not respect the spelling conventions of minority names provided there is phonetic equivalence, this regulation could be perceived as epitomising the EU policy regarding PNs. The wording is very tentative and cautious so as to leave the maximum leeway for the member states. More information as to the ideally envisaged situation is to be found elsewhere: for instance, in the 2005 opinion on Kosovo, a draft law is welcomed that would provide for registering names of minority members "in their original form, in the script and according to the tradition and linguistic system of their language."

However, the process of monitoring the implementation of the FCNM shows that in practice apparently uniform European policy is not so uniform after all. For instance, in many member states personal names of minority members were forcibly changed in the past; in practice re-registration tends to be complicated or impossible. As the opinions of the Advisory Committee show, this is or used to be a problem in Albania (the Montenegrin minority), Bulgaria (the Turkish minority), the Czech Republic (especially Germans and Poles), Kosovo (non-Albanian minorities), Macedonia - FYROM (the Turkish minority), Montenegro (Albanians), Norway (especially Sami and Kven), and Ukraine.

Another controversy revolves around script differences. The way minority names were Latinized in Azerbaijan was criticized, even though in view of the explanatory report the Latinization itself was permissible. The opinion on Poland stressed the fact that the 2005 law did not provide for language-specific diacritics typical 
of Czech, Slovak, Lithuanian and German. The Turkish minority in Macedonia objected against the transcription of their names, although names can now be legally recorded in minority languages other than Macedonian (also when spoken by less than $20 \%$ of population) and in scripts other than Cyrillic.

Other problems were more country-specific. Thus the lack of the legal possibility to register patronyms (of the Russian minority) was an issue in Estonia. In Denmark, where the (state) Evangelical Lutheran Church is solely responsible for registering names (except for Southern Jutland, where civil registry exists), church registration implies naming as well. To be accepted, the name must be on the state-approved list. While some recent 'ethnic' additions have been made (Ali, Hassan), most items on the list are of West European origin. About a century old, the law was originally meant to stabilize the surname system in a transition from patronymics to inherited family names, as well as to protect the surnames of the gentry from usurpers (Alvarez 2004).

Name lists, on the other hand, can help promote minorities and raise their status. The 2 nd cycle of the FCNM monitoring acknowledges the efforts of the Hungarian government to adopt lists of admissible surnames and given names for national minorities. Of the 13 minorities, the lists of 12 are already adopted.

Specific reservations regarding Art. 11 of the FCNM are connected with the Roma minority. Some members of the Roma minority in Hungary, for instance, according to the opinion of the 1st monitoring cycle, feel "induced by social pressure to change their names so as to make them no longer identifiable as Roma." In Russia the names of the Roma children are often rejected by the officialdom as 'unusual', traditional Russian names being offered instead.

In Lithuania, according to a Resolution of the Supreme Council (Jan. 31, 1991), the names and forenames of citizens of a different ethnic origin must be written in the passport in Lithuanian letters according to their pronunciation, with or without Lithuanian suffixes (the choice is left to the person concerned). This became the chief objection in the 1st cycle of the FCNM monitoring. The main two minorities in Lithuania are Poles and Russians, each accounting for over $6 \%$, and both writing their names using letters other than Lithuanian. The 2005 government proposal for a new regulation for registering PNs was rejected by a parliamentary committee as 'unconstitutional', so the situation has not changed. The 
Lithuanization includes also famous historical figures: the 19th century heroine of a national Polish uprising, of Livonian extraction, Emilia Plater, became the hardly recognizable Emilija Pliateryte. A case has recently been brought by the Polish minority against Lithuania before the European Court of Human Rights, regarding the name of a secondary school in Lawaryszki, named after her (Interpelacja 2008, Naniewicz 2008).

The feminine suffix on surnames is a bone of contention in some EU member states. The 1st cycle monitoring found that the Slovak form of feminine surnames is still imposed on some national minorities. As the Slovak government replied, "foreign language female surnames can also be used without the Slovak form" (it is not clear if foreign language equals minority language or not). In Serbia, on the other hand, the problem was, conversely, the lack of the feminine suffix required by the grammar of such languages as Macedonian, Slovak, Bulgarian and Ruthenian.

Germany was not included in the comments regarding Article 11 of FCNM, yet the situation in this member state occasions a comment. For Sorbs in Lusatia, the choice of name is not restricted by any official list, but the officially recognised form of the given name and surname (in passports or birth registers) must be German. The Sorbian version may be used in regional periodicals and books, in membership cards of regional organisations and in Sorbian schools, as well as privately (Rzetelska-Feleszko, Cieślikowa, and Duma 2002: 272). It is worth noting that also in Nazi times Sorbian PNs in identification documents were adjusted to the German spelling conventions or replaced altogether with German variants. A person by the surname of Schirgiswalde, born 1928, recollects the duty to write this surname for a couple of years in Nazi times with 's-c-h', i.e. the German way (Bott-Bodenhausen 1997: 40). Paradoxically, the surname corresponds to a place name in Lusatia (Šérachów), which shows that the surname itself has already been Germanised.

France, which never signed the FCNM, has a long-standing tradition of restrictive policies regarding minorities. In 1794 the Report on the Necessity and Means to Annihilate the Patois and to Universalise the Use of the French Language by Henri Gregoire, one of the leaders of the French Revolution, was published. A 1803 law on names in revolutionary France stated that "the names in use in the various calendars, and those of personages known in ancient history, are the only ones that can be accepted, as first 
names, on birth certificates; and it is forbidden for public officials to allow any other names in their acts" (Liberman 2008). This law, effectively excluding regional names, remained in effect until 1966, when some more categories, among them regional names, were allowed. In 1999 a Breton couple living in New Caledonia wanted to give their son the Breton version of the French name Corentin. While the judge accepted the name as traditionally Breton, the head prosecutor of Nouméa appealed the ruling, calling the name 'barbaric-sounding' (An Tour Tan 1999). The ruling was finally upheld in May 2000 (Liberman 2008), but the prosecutor's behaviour in what came to be known as 'l'affaire Kawrantin' can be seen as yet another example of the conviction, espoused by the French state, that the centralized French culture - as manifested, among others, in given names - is superior to any (minority) cultures there might be in France, metropolitan or overseas.

\section{Conclusions}

LP regarding personal names is only a small and perhaps somewhat neglected aspect of a country's overall LP, yet it is vital for the identity of an individual, because names themselves mark our self-identity. In the words of Valerie Alia, "the politics of naming has never been defined as such but has existed between the lines of many disciplines" (2009). This is why history abounds in attempts on the part of those in power to influence the shape of PNs. With regard to surnames or surnames combined with given names, this influence frequently equalled erasing the characteristic features of a minority language so as to give the false impression that the minority does not exist and to create the illusion of a homogeneous nation state. With regard to given names, the practices were manifold, including enforcing a list of forbidden (or, conversely, allowed) names; translating names from a minority to the dominant language, disregarding the spelling conventions of the minority language; or, as an extreme measure, even forcibly having everybody from an ethnic minority bear the same given name as stigma. Even though in contemporary Europe the measures adopted by language regulators are not quite so drastic, in the eyes of national or ethnic minorities the situation is far from satisfactory. Sometimes name changes or modifications are voluntary and encouraged rather than enforced, as in the case of immigrants re- 
nouncing their previous identity to integrate better into their host country and to enhance their job prospects. Such 'soft' methods may be harder to perceive (and not as visible to the media), yet the changes they lead to might be just as sweeping.

Finally, it is important to bear in mind that some degree of political organization of a society (as well as a means to enforce law) is required to speak of LP at all. Thus a local taboo forbidding the use of the name of the new chieftain for newborns can hardly be considered a LP - in contrast with the 1985 Thai name law, which makes it illegal to register a name resembling the king's name (Jernudd 1995: 121). Besides, not all regulations regarding PNs qualify as LP. The common-sense regulation that a name should not be offensive or subject its bearer to ridicule can hardly be treated as a minority LP; even those policies that do influence minorities are not necessarily directed against them. A case in point may be the regulation present (at least theoretically) in many European countries forbidding parents to create new given names for their offspring and urging them instead to choose from an officially approved name list. As long as minority given names feature on the list (or there is a separate list of minority names), the existence of such a list is by no means a violation of minority rights.

\section{Address:}

Justyna Walkowiak

Collegium Cegielskiego

Ul. 28 Czerwca 1956, No 198

61-485 Poznań

Poland

E-mail: justwalk@amu.edu.pl

\section{References}

Alia, V. (2009) Names and Nunavut. Culture and identity in the Inuit homeland. NewYork and Oxford: Berghahn Books.

Alvarez, L. (2004) "Jens and Vita, but Molli? Danes favor common names". The New York Times International. Retrieved Oct. 30, 2009, from http:// www.nytimes.com/2004/10/08/international/europe/08names.html

Andrews, S., J. Quintero, and S. O'Brien (2007) Canary Islands. Footscray, Victoria: Lonely Planet.

Angelov, A. G. and D. F. Marshall (2006) "Introduction: ethnolinguistic minority 
language policies in Bulgaria and their Balkan context”. International Journal of the Sociology of Language 179, 1-28.

An Tour Tan. Archives de l'actualité bretonne (1999) Retrieved Oct. 29, 2009, from http://www.antourtan.com/actualite/19991213.html

Błaszczyk, J. et al., eds. (2006) Zachować od zapomnienia. Rozmowy o przeszłości z Pomorzanami. [Saving from oblivion: talking about the past with Pomeranians.] Gmina Chełmża: Stow. Homo Homini.

Bott-Bodenhausen, K. (1997) Sprachverfolgung in der NS-Zeit: sorbische Zeitzeugen berichten. Bautzen: Domowina-Verlag.

Breza, E. (2008) "Standaryzowane imiona kaszubskie". [Standardized Kashub names.] Biuletyn Rady Języka Kaszubskiego (Gdańsk) 2008.

Couretas, J. (2008) "An Orthodox view of contemporary economics, politics, and culture". The Information Service of the Serbian Orthodox Church. Retrieved April 13, 2009, from http://www.spc.rs/eng/orthodox_view_ contemporary_economics_politics_and_culture

Crawford, J. (2009) http://ourworld.compuserve.com/homepages/ JWCRAWFORD/langpol.htm, Retrieved April 30, 2009. ${ }^{145}$

Dizdar, Z. (2005) "Italian policies toward Croatians in occupied territories during the Second World War". Review of Croatian History 1, 179-210.

Eberhardt, P. (2005) "Problematyka narodowościowa Bułgarii w XX wieku”. [Ethnic issues in Bulgaria in the 20th century.] Sprawy Narodowościowe 27, 53-70.

Eire, C. M. N. (1986) War against the idols: the reformation of worship from Erasmus to Calvin. Cambridge: Cambridge University Press.

George, A. (2005) Jordan: living in the crossfire. London: Zed Books.

Gorrochategui, J. (1995) “Basque names”. In E. Eichler, G. Hilty, H. Löffler, H. Steiner, and L. Zgusta, eds. Namenforschung : ein internationales Handbuch zur Onomastik. 1. Teilband, 747-756. Berlin and New York: Walter de Gruyter.

Huebner, T., K.A Davis, and J. Lo Bianco (1999) Sociopolitical perspectives on language policy and planning in the USA. Amsterdam and Philadelphia: John Benjamins.

Interpelacja $n r 5649$ do ministra spraw zagranicznych $w$ sprawie sprzeciwu władz litewskich wobec polskiej pisowni patrona szkoły średniej w Ławaryszkach w rejonie wileńskim (2008, Oct. 9). [Interpellation No 5649 to Foreign Minister regarding Lithuania's objection to the Polish spelling of the name of the person after whom the Lawaryszki secondary school is named.] Retrieved Oct. 29, 2009, from http://orka2.sejm.gov.pl/IZ6.nsf/main/ 5B22CE02

5 The link is no longer active; the quotation can be found in Huebner et al. 1999: 2 
Jernudd, B. H. (1995) "Personal names and human rights". In T. Skutnabb-Kangas, R. Phillipson, and M. Rannut, linguistic human rights: overcoming linguistic discrimination. Berlin and New York: Mouton de Gruyter.

Karagiannis, E. (2005) Flexibilität und Definizionsvielfalt pomakischer Marginalität. Wiesbaden: Harrassowitz Verlag.

Kloss, H. (1969) Research possibilities on group bilingualism: a report. Quebec: International Center for Research on Bilingualism.

Kulavkova, K. (2007) "Hermeneutics of the ethnic identity and the territorialism". Sprawy Narodowościowe 31, 81-95.

Liberman, M. (2008) “The academy strikes back”. Retrieved 27.04.2009 from http://languagelog.ldc.upenn.edu/nll/?p=336

Liddicoat, A. J. (2005) “Corpus planning: syllabus and materials development”. In E. Hinkel. Handbook of research in second language teaching and learning, 993-1012. Mahwah, N.J.: Erlbaum.

Linek, B. (1997) Odniemczanie województwa śląskiego w latach 1945-1950 (w świetle materiatów wojewódzkich). [De-Germanizing the Silesian voyvodeship 1945-1950 (in the light of the voyvodeship documents).] Opole: Wyd. Instytut Śląski.

Madajczyk, P. (1999) „Znaczenie języka polskiego na Górnym Śląsku w latach 1921-1950". [The role of Polish in Upper Silesia 1921-1950.] Referat wygłoszony podczas spotkania w Domu Współpracy Polsko-Niemieckiej 2-5.11.1999, Gliwice. Retrieved May 6, 2009, from www.haus.pl/pl/pdf/ pub1/11.pdf

Majuk, E. (n.d.) "Pomacy i Torbesze". [The Pomaks and the Torbeshi.] Panorama Kultur, retrieved March 26, 2009, from http://www.pk.org.pl/ artykul.php?id=333

Malec, M. (2001) Imię w polskiej antroponimii i kulturze. [The given name in the Polish anthroponymy and culture]. Kraków: Wyd. Naukowe DWN.

Matusz, J. (2008) “Chrześniacy prezydenta Mościckiego”. [President Moscicki’s godsons.] Rzeczpospolita November 10-11, 263.

McKim, D. K. (2004) The Cambridge companion to John Calvin. Cambridge: Cambridge University Press.

"Modernization" (n.d.) Wikipedia. Retrieved April 16, 2009, from http:// en.wikipedia.org/wiki/Language_planning

Naniewicz, B. (2008) "Mecenas Rafał Kasprzyk zajął się obroną Polaków na Litwie". Kurier Wileński October 7. Retrieved May 16, 2009, from http:/ /kurierwilenski.lt/pdf-archiwum/KW_2008_10_07.pdf

Naphy, W. G. (2003) Calvin and the consolidation of the Genevan reformation. Westminster: John Knox Press.

Ponikelska, L. (2004) "Law would mean surname options". The Prague Post March 4. Retrieved Oct. 30, 2009, from http://www.thepraguepost.com/ P03/2004/Art/0304/news7.php 
Rzetelska-Feleszko, E. (2003-2004) "Onomastyka chorwacka w perspektywie ogólnosłowiańskiej”. [Croatian Onomastics in the all-Slavonic perspective.] Folia Onomastica Croatica, 12-13.

Rzetelska-Feleszko, E., A. Cieślikowa, and J. Duma (2002) Słowiańska onomastyka: encyklopedia. T. 1. Warszawa-Kraków: Towarzystwo Naukowe Warszawskie.

Sarnowska-Giefing, I. (2003) “Imiona poznaniaków w latach 1939-1945”. [Names of the inhabitants of Poznań in the years 1939-1945.] Poznańskie Spotkania Językoznawcze 11.

Schiffman, H. F. (1998) Linguistic culture and language policy. London and New York: Routledge.

Shohamy, E. (2006) Language policy: hidden agendas and new approaches. London and New York: Routledge.

Skutnabb-Kangas, T. and S. Bucak (1995) "Killing a mother tongue - how the Kurds are deprived of linguistic human rights”. In T. Skutnabb-Kangas, R. Phillipson, and M. Rannut, eds. Linguistic human rights: overcoming linguistic discrimination, 347-371. Berlin and New York: Mouton de Gruyter.

Spolsky, B. and E. Shohamy (1999) The languages of Israel: policy, ideology and practice. Clevedon and Buffalo: Multilingual Matters.

Superanskaja, A. V. (1995) "Eastern Slavic names”. In E. Eichler, G. Hilty, H. Löffler, H. Steiner, and L. Zgusta, eds. Namenforschung: ein internationales Handbuch zur Onomastik. 1. Teilband, 812-815. Berlin and New York: Walter de Gruyter.

Szczerkowski, P. (2007) “Holenderski imigrant walczy z muzułmańskimi imionami”. [A Dutch immigrant fights Muslim names.] Gazeta Wyborcza June 2.

Umińska-Tytoń, E. (1988) "Imiona łodzian urodzonych podczas okupacji hitlerowskiej". [Names of the inhabitants of Łódź born under the Nazi occupation.] Onomastica 32.

Ustawa z dn. 3.03.2005 o zmianie ustawy o zmianie imion i nazwisk oraz o zmianie niektórych in. Ustaw. [The law of name changes and related regulations.] Dziennik Ustaw $2005 \mathrm{nr}$ 62, poz. 550.

"Zalecenia dla urzędów stanu cywilnego dotyczące nadawania imion dzieciom osób obywatelstwa polskiego i narodowości polskiej”. [Guidelines for registry offices regarding names for children of Polish citizens of Polish nationality.] (1996) Komunikat Komisji Kultury Języka 1, 4.

Zanga, L. (1986) "Albania”. Religious trends in Eastern Europe. Radio Free Europe Research, RAD Background Report 139, 7-9. 
Kokkuvte. Justyna Walkowiak: Vähemuskeele poliitika seoses isikunimedega - ülevaade. Keelepoliitika koos keele planeerimise kui rakendamisega on tänapäevaks väljakujunenud ala. Ometi on see harva seotud isikunimedega, sellest annab tunnistust akadeemilise kirjanduse puudumine. Artikkel vaatleb isikunimesid (ees- ja perekonnanimesid) ning arutleb viiside üle, kuidas neid saab tajuda vähemuskeele poliitika objektidena. Isikunimedega seotud strateegiaid analüüsitakse keeleplaneerimise traditsioonilises raamistikus. Neid strateegiaid on artikli edasises osas uuritud vastavalt teiste tasanditega: mis on keelepoliitika objektid, kes on selle esindajad, mis motiveerib keelepoliitikat, milliseid mõjusid see avaldab ja kuidas keelepoliitikat teostatakse. Artikli lõpus vaadeldakse Euroopa Liidu vähemuste õigusakte seoses isikunimedega, sh eri maadega seotud valikuid, mis peegelduvad rahvusvähemuste kaitse raamkonventsiooni seireprotsessis, tõstes esile poleemikapiirkondi. Kokkuvõttes näidatakse, kui vitaalsed on isikunimed isiku- ja grupiidentiteedis ja seega ka seda, kuidas nende kontrollimine aitab kontrollida vähemusi, kuigi on väidetud, et iga regulatsioon ei kehtesta vähemuskeele poliitikat.

Märksõnad: keelepoliitika, vähemused, isikunimed, perekonnanimed, eesnimed 